\title{
Dualism of Utopia: Anti-Systemic Protest and Social
}

\author{
Gleb D. Leontyev, Ludmila S. Leontieva
}

\begin{abstract}
They performed the analysis of utopia phenomenon as a social alternative. From the standpoint of the socio-synergetic approach, the following task was posed: to justify the design and protest nature of the utopian worldview. The relationship between the formation and translation of social utopia and the level of social self-organization is affirmed. An inverse correlation with the process of self-organization of citizens is characteristic of political ideology. Based on this, the phenomena of "utopia" and "ideology" are considered as worldview opposites. The existential basis of mass consciousness protest state is constituted by the conviction of the idea of utopian due and despair conditioned by the unsatisfying being. In accordance with the classification of social protests, the type of protest in the context of utopian discourse is defined by the authors as anti-systemic. The utopian project becomes the ideological engine of this social protest. Denial in the form of protest and construction in the form of a project determine the critical constructive nature of utopia. Therefore, the suppression of utopian ideas is considered in the article as the rejection of socio-political thinking projectivity, and therefore, as an approximation of social stagnation. The praxeological features of utopia are manifested in the presence of both an ideal and a real component, i.e. this is a project that changes the state of mass consciousness, and this is a practice that transforms social reality. Along with the humanistic optimism of utopia, they single out the risk of "denial of denial," that is, the denial of the very utopian idea of an "ideal" society in the practical implementation of a utopian project.
\end{abstract}

Keywords: utopia, ideal, social project, social protest, ideology, state.

\section{INTRODUCTION}

The relevance of social utopia study is conditioned by the general political and economic dynamics of the post-industrial period, the search for social alternatives to the "consumer society", as well as by the changes in the social mood of Russian society. According to Levada Center studies, social well-being worsened on the Social and Consumer Sentiment Indices in 2018. According to $78 \%$ of Russians, in 2019 the number of fellow citizens dissatisfied with the government is growing [1]. Thus, the search for an integrating national idea, a "special way" for the development of Russia, and other forms of socio-state system improvement is intensifying.

The situations of a growing social crisis in the presence of potential opportunities for the reform and modernization process are a favorable environment for the development of a utopian worldview. Given that one of the reasons for the negative attitude towards utopia is its identification with the

Revised Manuscript Received on November 08, 2019.

* Correspondence Author

Gleb D. Leontyev, Kazan Federal University

Ludmila S. Leontieva, Kazan Federal University phenomena of totalitarian ideologies, it is necessary to separate these concepts. Therefore, the purpose of the study is a kind of "rehabilitation" of social utopia as a humanistic phenomenon by substantiating its design and protest nature.

The Utopian Discourse Information Base is a critical interpretation of the present environment. The difference between the negative understanding of utopia as a barren phenomenon ("utopistisch") and its constructive, projective understanding ("utopisch") $[2,3]$ lies in the correlation of the ideal model with the objective trends of social development, i.e. finding alternative codes in being "here and now", synergistic determination by the future.

It is a critically reflective analysis of the existing order that allows us to argue that utopian discourse is not illusory-subjectivist ideas that arose in the context of undeveloped production relations, but actual information and communication relations that create programmatic grounds for the opposition for the practical transformation of the social system.

\section{METHODS}

The study is based on socio-synergetic methodology. The logic of utopian thinking is built in the direction from the due to the existing. A leading reflection of reality reveals the synergistic principle of determination by the future, according to which utopian constructs are already present as trends in the present. Their activation at the level of individual and public consciousness is characteristic of social entropy and chaos situation, and the social-utopian ideal acts as an attractor of the protest movement. Belief in its feasibility is explained by the "principle of Hope" by the German philosopher E. Bloch, on the basis of which utopia is self-generated in the ontology "Noch-Nicht-Sein" ("Still-Not-Being"). A specific utopia transforms being here and now. Therefore, a warning about the danger of its ideological "mutation" is represented by the ideas of K. Mannheim on the principles of distinguishing between utopia and ideology and the idea of K. Popper on the risks of the total "Utopean social engineering" [4].

\section{RESULTS AND DISCUSSION}

The activation of utopian thought is characteristic of crisis periods, when the system at the bifurcation point makes a tense choice of possible social alternatives. Utopian ideas are those fluctuations that undermine the socio-political system. Utopian injections of this kind are an axiological articulation of a social position, which suggests the direction of the optimal social development demanded by the public consciousness. In this regard, social utopia can be regarded as intuition in the structure of 
society self-regulation, as self-preservation of the social, and therefore as a regulatory phenomenon. A future-oriented utopia motivates the adjustment of the present in accordance with the current intentions of the social system. Thus, a transformed society gains the ability to maintain its integrity and vitality. Therefore, muffling, the rejection of utopian discourse is the rejection of its regulatory, transformative capabilities. The lack of a value-idealized reaction to the imperfections of the real world provokes another era of "stagnation" with the derogatory attitude of the prevailing ideology towards utopia as "utopistisch" ("utopian"), socially unacceptable, and barren. According to K. Mannheim, the complete "disappearance of utopia will create a static thingness in which a person will turn into a thing" [5, p. 169]. Therefore, the scholar connects the "will to create history and the ability to understand it" with the will to utopia, and therefore, the ability to recognize the dichotomy between the experience of the "empirical city" and the impulse to the ideal city. This rush to the future in the context of an unsatisfactory present manifests itself in social protest. A socio-utopian project becomes the ideological and philosophical basis of the protest. Thus, the transformation of reality under the influence of utopian consciousness is carried out in a protest-design form.

Modern researchers distinguish three main types of social protest: prosystemic protest as a reform in the logic of the existing system; off-system protest as an individual sociocultural rebellion that does not offer constructive alternatives; anti-systemic protest as a complex of conflict actions aimed at a radical transformation of the social order $[6,11,12]$. Let's consider this typology in relation to utopia as a form of social protest. The first type of protest does not contain radical opposition, while utopia denies present reality. The second type of protest is beyond direct opposition to the social system. It is limited to escapades at the level of individual being, while utopia is a systematic social project of a better future for many, the scale depends on the author's ambitions. Based on the fact that utopia, as an alternative, denies and constructs, it can be attributed to the third, anti-systemic type of protest. The development of a program for such a protest involves articulation of critical and constructive ideas. The protest against the injustices of the world of existence, expressed in the text of a work of art, becomes a social media event in any other public circulation, a "place of assembly" according to the terminology of synergetics. If the opposition search for the "ideal" corresponds to the mass mood, then the discourse deepens and expands. Thus, a utopian idea can become a factor of the social environment transformation. But an idea becomes a utopian project only if there is an aim for practical implementation during specific methods of practical action development.

If the protest-project characteristics of the utopian are the form of the transforming process, then its content is associated with the concept of practice. In accordance with the main constituent elements of practice, the goal of reality transformation into utopia is an ideal state based on the principles of justice, equality and the common good. The object of transformation is current reality, with alienating conditions of being. Often, the means of transformation mental operations and empirical methods, - are not only mental, but also an experimental experiment. The condition for transformation is the strategic level of activity when the author is the creator of a new, sought-after reality. The result of the transformation is a perfect state, whose living arrangement corresponds to a specific historical target. The basis of transformative practice is expedient activity, when a conscious need is satisfied by adequate means, and goal-setting implies a choice between the means and the results corresponding to them.

The goal-oriented transformative activity in the process of utopian discourse is carried out in two aspects: in reality this is practice, the actual transformation of social life through reforms and revolutions, and ideally - this is a project, the changes in the mental space, in the attitudes of citizens. Project activities products provide the opportunity for practical changes. Therefore, a utopian project is an indispensable component of the utopian transformation of reality. However, its full realization denies utopia itself. The "moral madness" of the utopian plan "is revealed only in practice when this ideal takes control of the will" [7, p. 127], S.L. Frank wrote, exploring the "diabolical paradox of moral dialectics" of good and evil, holiness and sadism of the utopian "heresy." K. Popper sees the social negativity of total "utopian engineering" in the demand for a strong centralized "power of the few" and, thus, in the distortion of the original ideal, the empirical "slipping" of utopia into anti-utopia, as evidenced by the "state precedent for the implementation of European ideas about the communist future" in the Soviet Union [8]. But, despite its "mutations", utopia exists, and will exist, thanks to the universality of the values it proclaims. The Utopian ideal, contrary to the pessimistic view of Utopia, humanizes social practice not only in the aspect of the future, but "here and now", being an impulse of a conscious, reflective-value attitude to the world. As the manifestation of the cognitive orientation of utopian consciousness, the social ideal becomes part of social practice, fixing the optimal "growth points". To comprehend the praxeological aspect of utopian design, the classification of F. Ains utopias is relevant. Turning to the origins of the genre - the works by $\mathrm{T}$. More and T. Campanella, the Spanish researcher identifies two types of utopias: the utopias of freedom, recreating the "ideal state of man" and utopias of order, describing the "ideal citizen of the State" [3]. It is the latter type of utopia that tends to degenerate into dystopia. The mechanism of rebirth is the ideologization and dogmatization of once viable, human-oriented ideas. The utopias of the maximum of individual freedom do not deny normativity as a form of social interaction and the means of overcoming chaos, but recognize its creative functions as chaos and, therefore, the freedom of social creativity for society and an individual Rationality and morality are united in the space of utopia, therefore its freedom has a positive meaning [9, 13,14]: this is not only freedom "from" the unsatisfying forms of being, but also the freedom "for" the creation of the desired.

The practical goals of the utopian ideal introduction and spreading are socio-political in nature for the most part. Perhaps that is why some researchers speak of utopia as an element of the ideological system of society. Such a formulation is valid if we consider ideology in terms of form, i.e. as a field of signs in the context of semiotics or as theoretical knowledge, i.e. as a level of public consciousness along with social psychology. Then utopia, like any other sign-theoretical phenomenon, is an integral part of ideology. 
However, in terms of content and socio-group approach, ideology is the self-consciousness of a social group. The purpose of ideology is to justify the legitimacy of political subject actions. When you compare ideology and utopia, it is legitimate to focus on the political sphere, since utopia is the simulation of ideal statehood, i.e. it is about social and managerial problem solution. However, utopia acquires a practical connection with politics only when it claims to implement its project, that is, when individuals appear who are motivated by political competition and are able to mobilize the masses. Before the stage of practical implementation, this is the socio-cultural sphere of philosophical and literary creation. Of course, it cannot be ruled out that legal authorities may consider the exaggeration of protest-utopian ideas as a potential danger to their stability. Trying to block the transformation of mass consciousness, the ruling subject includes the mechanisms of informational propaganda and administrative-force countermeasures, thereby translating the utopian into the political sphere, i.e. in the sphere of the struggle for power and authority implementation. In this situation, utopia as a protest worldview is opposed to the dominant ideology, which "seeks to maintain or constantly reproduce the existing way of life" (K. Mannheim) [4, p. 113]. Given the lack of identity between utopia and ideology in the presence of a value relation of utopian consciousness to reality, we can consider utopia as an element of the value-worldview, and not the political, ideological system of society. In the terminology of the science of logic, ideology is a distributed subject of judgment "all ideologies are worldviews", since its volume is fully included in the volume of the predicate-worldview, while the volume of the predicate is only partially included in the volume of the subject-ideology, because other phenomena, such as utopia, are also worldviews. A utopian worldview is a spirit and a rush to the future, utopia shakes the status quo, while ideology is a system of ideas that legitimize political power. "The function of ideology is not to offer us a point of escape from our reality but to offer us the social reality itself as an escape" (S. Zizek) [10]. This formulation of the Slovenian philosopher, in our opinion, represents utopia as the opposite of ideology. Paraphrasing the first part of the statement, we get the following statement: if the utopia in its functional execution offers us "a way to escape from reality", then the function of ideology is "to present social reality itself as a shelter from some traumatic, real essence". That is, if a utopian project is an escape from reality into another "ideal" dimension through escapism or heroic reconstruction, then the ideological system justifies the existing as the best, "protecting" the individual from the symbolically masked realities of being. The ideological construct is the opposite of utopia per se and at the same time can be compared with it as a worldview phenomenon. The second aspect of utopia and the prevailing ideology correlation relates to the concept of the state: both phenomena are preoccupied with its status. Thus, on the one hand the theories of the ideal, legal (Rule of law) social, participatory state are born, and on the other hand - the apologetics of legal statehood.

\section{SUMMARY}

The theoretical analysis of the phenomenon under study allows us to state: 1) the presence of a direct correlation between the intensity of socio-utopian idea development and the level of socio-political self-organization; 2) the lack of identity between the ideological phenomena of "utopia" and "ideology" along the coordinate axes "humanization totalitarianism", "alternative - apologetics of the existing"; 3) the immanence of a social protest of an anti-systemic type to a utopian worldview, its critical constructive nature; 4) the dual trend of the praxeological component of utopia is a project that transforms mass consciousness and it is the practice that transforms social reality through radical or reformist actions; 5) "denial of denial" in the utopian discourse, namely: the utopian project formed in the framework of social protest denies utopia itself in practice.

\section{CONCLUSIONS}

Thus, the attributive property of utopian consciousness is an optimistic belief in the possibility of the ideal implementation. Future-oriented conviction, on the one hand, and despair, caused by the present, on the other hand, create the existential basis of the protest state of mass consciousness. The utopian project becomes the ideological engine of social protest. Denial in the form of protest and construction in the form of a project are the opposite sides of one phenomenon an ideal utopian-oriented consciousness.

\section{ACKNOWLEDGEMENTS}

The work is performed according to the Russian Government Program of Competitive Growth of Kazan Federal University.

\section{REFERENCES}

1. Levada Center. Press releases 16.05.2019, 04.06.2019. URL: https://www.levada.ru/2019/05/16/sberezheniya-rossiyan/; https://www.levada.ru/2019/06/04/protestnyj-potentsial-9/

2. Bloch, E. The spirit of Utopia. [Electronic resource]. - Standford Stanford University Press, 2000. - 320 p. - URL: https://kupdf.com/download/bloch-ernst-spirit-utopia_58d15501dc0d 60c608c34614_pdf

3. Ainsa F. La Reconstruccion de la Utopia. Mexico. Correo de la UNESCO. 1999. - 238 pp.

4. Popper, Karl Raimand. The Open Society and Its Enemies. Vol. II. The High Tide of Prophecy : Hegel, Marx, and the Aftermath / K. R. Popper. - 5th ed. - London ; Routledge \& Kegan Paul, 1966.- 420 pp

5. Utopia and Utopian thinking / Comp., ed. by V.A. Chalikova. - M.: Progress, 1991. - 405 p.

6. Maksimov M.A. The problem of the subject of antisystem activity in modern philosophical thought. // Policy. Political Studies. - 2010. - No. 4. - pp. 159-171.

7. Frank S.L. Heresy of utopianism // On the other side of the right and left. - Paris, 1972.- pp. 126-134.

8. Leontyev G.D., Leontieva L.S., Khalilova T.V. Implementation of state utopia: issues of property and freedom / // 5th International Multidisciplinary Scientific Conference on Social Sciences and Arts SGEM 2018, www.sgemsocial.org, SGEM2018 Conference Proceedings, ISBN 978-619-7408-64-5 / ISSN 2367-5659, 26 August - 1 September, 2018, Vol. 5, Issue 1.4, 383-390 pp.

9. Leontiev G.D. The Utopian Trajectory: From Due to Existence // NB Sociodynamics. - 2017. - № 4. - pp. 126-136. DOI 10.7256/2409-7144.2017.4.22751.- URL http://e-notabene.ru/pr/article_22751.html

10. Slavoj Žižek. The Sublime Object of Ideology. - Verso, 1989. - 240 p

11. Selomo, M. R., \& Govender, K. K. Procurement and Supply Chain Management in Government Institutions: A Case Study of Select Departments in the Limpopo Province, South Africa. (2016).

12. Laureano, R. M., Fernandes, A. L., Hassamo, S., \& Alturas, B. (2018). Facebook satisfaction and its impacts on fundraising: a case study at a Portuguese non-profit organization. Journal of Information Systems Engineering and Management, (1). 
13. García-Santillán, A. (2019). An Algorithm to Renegotiate Debt through Equivalent Equations and Transaction Costs: A Proposal for the Field of Financial Education. International Electronic Journal of $\begin{array}{lll}\text { Mathematics } & \text { Education, } & 14(1),\end{array}$ https://doi.org/10.12973/iejme/3981

14. Abishov, S., Polyak, D., Seidullaeva, G., \& Kermeshova, Z. (2018). Meaning of fiction in formation of studentsidentity. Opción, 34(85-2), 186-204. 